\title{
Application of Passive Cooling Technologies in Commercial Buildings
}

\author{
P. A. Hangargekar, K. R. Harne
}

\begin{abstract}
World over building sector is largest consumer of electrical energy. Energy requirement for air cooling and refrigeration is found to be $40 \%$ of total consumption of electrical energy used in building sector. Passive cooling technologies used in building have good potential of indoor air cooling many building built on these principles are showing reduction in energy requirements. In present work, passive cooling technologies such as planform, shading devices, garden trap bond, fenestration, air ducts, earth berming, and indoor gypsum wall finishes, false ceiling etc. had been integrated into building design of a commercial building at Tuljapur in the hot and dry climatic zone of India. Field experimentation work of measurement of temperatures in indoor and outdoor locations of the building had been conducted to assess the cooling potential of these technologies. It was found that average temperature reduction in indoor atmosphere was archived as $3^{\circ} \mathrm{C}$ except the temperature difference between indoor and outdoor atmosphere. This was a cumulative effect of above mentioned passive cooling technologies integrated in building design.
\end{abstract}

Keywords: passive cooling, temperature, relative humidity, energy conservation

\section{INTRODUCTION}

In the ancient period, our forefathers had developed construction techniques for houses and other types of buildings the objective was to maintain comfortable indoor conditions this was achieved by the use of locally available materials and particular design of building elements. The design of building elements was done to create comfortable indoor air quality against the variable outdoor climatic conditions.[1] Ancient buildings were using liquid fuels for lightening the lamps and indoor air cooling needs were satisfied with passive cooling technologies, applied in building without using an external power source. In the modern period, due to the advancement of science and technology new fuels and energy sources have been utilized for daily needs this usage has created ill effects on the environment such as global warming, etc. This is an important need for the human being to control pollution issues and to safeguard mother earth.

As per CPWD 2004 report, in India, 40\% of electrical energy is consumed by indoor space air conditioning and refrigeration. [8] This huge energy requirement can be lowered by the implementation of passive cooling techniques

Revised Manuscript Received on February 05, 2020

* Correspondence Author

P. A. Hangargekar, Research scholar, MGM'S JNEC, Aurangabad, India. E-mail: pradeeppah@gmail.com

Dr. K .R. Harne, Professor, Department of CE,CBP Government college of engineering New Delhi, India. E-mail: harnekr64@yahoo.co.in

(c) The Authors. Published by Blue Eyes Intelligence Engineering and Sciences Publication (BEIESP). This is an open access article under the CC BY-NC-ND license (http://creativecommons.org/licenses/by-nc-nd/4.0/) in building design aroused from traditional knowledge. In present work, a commercial building in the hot and dry climatic zone at Tuljapur $\left(18.01^{\circ} \mathrm{N}\right.$ and $\left.76.07^{\circ} \mathrm{E}\right)$ District Osmanabad (India) is studied for various passive air-cooling technologies used in it. The building is three-storied with partial underground floor and ground floor as commercial shops and first floor built as lodging area. Experimentation conducted to collect data related to temperature variation at various places in the building during the hotter day of summer. Its graphical analysis shows a reduction in temperature by application these cooling techniques when compared to the base case of a conventional building without any passive cooling aids.

\section{LITERATURE REVIEW}

Nejat et.al [3] review paper on passive cooling states that buildings account for $40 \%$ of the total world emissions and $30 \%$ of electrical consumption. Air conditioning systems consume more than $60 \%$ of the electrical energy produced.

Macias et al [5] describe the optimisation of solar gain through windows on the south and east sides. He used solar chimney since solar irradiation was high and prevailing wind speed was low. It has been shown that by applying low-cost concepts the energy demand can be reduced. It has been demonstrated by Pablo et al [8] with experimentation that ventilative cooling is used with a smart thermostat to reduce the maximum temperature inside building in warm climates. It has been proved that more wall mass with blinds outside can perform better than less wall mass with the inside blind. He concluded that passive cooling systems are a viable option in developing countries with hot and dry climate zones Thomas et.al [9] had examined the energy conservation potential of passive cooling systems. The research laboratory building Torrent research center (TRC) Ahmedabad (India) proves that passive downdraft evaporative cooling (PDEC) system and other passive cooling strategies can improve indoor air quality if integrated with the design of the building. This concept of integrated building design consisting of passive cooling technologies had been applied in the present study of a commercial building.

\section{PASSIVE COOLING TECHNOLOGIES APPLIED IN COMMERCIAL BUILDING}

As per the existing site conditions of the commercial building, entrance of building is from the west direction with a narrow path of 7 meters wide between two adjoining buildings on both sides. This induces hot and speedy wind from west directions towards the building. The area of the opening provided in the building is less than $10 \%$ of the floor area for every room to control the excess ambient heat and wind. 


\section{Application of Passive Cooling Technologies in Commercial Buildings}

The existing landform is studied for solar radiation by drawing the Sun path diagram for this plot as per Inanlou et.al [2] has proved that area of openings to reduce the solar heat the sizes of windows in East and West direction can be kept lesser than south and north directions. Nayak et.al [6] explored if the planform of the building is designed as a square-shaped the surface to volume ratio is $=1.67$ is directly proportional to direct heat gain or loss. In the present commercial building, it was kept as [21.34 m x $21.34 \mathrm{~m}$ ] this had reduced solar heat gain from the roof.

The shading of the opening area is done by box type fully covered chajja unique fully glazed window size of $1.2 \mathrm{~m} \mathrm{x}$ $1.2 \mathrm{~m}$. with a triangular transom fixed glass window of $1.2 \mathrm{~m}$ wide above it was designed. The box chajja provided from four sides shade the window from sun rays entering inside the windows. (Fig.1) this ensures the entry of sunlight without solar heat inside the room to avoid indoor air heating. Windows are covered with movable curtains internally. The commercial building is 10.5 meters in height. It was being shaded from the western side by another existing building to $50 \%$ of its width and its total height. This shading protects the commercial building from sunlight heating, wind speed and rainfall from the west direction. A tapered chajja of $0.75 \mathrm{~m}$ wide was provided from all four sides protects the ground floor from rainfall and solar radiation.

The roof absorbs $38 \%$ heat from an ambient atmosphere of thermal conduction is protected by providing a gypsum sheet false ceiling of a commercial building. (Fig.2)

The heat from the roof is protected by providing gypsum board false ceiling 0.6 meters below roof slab to control solar heat transmission to indoor air of rooms.

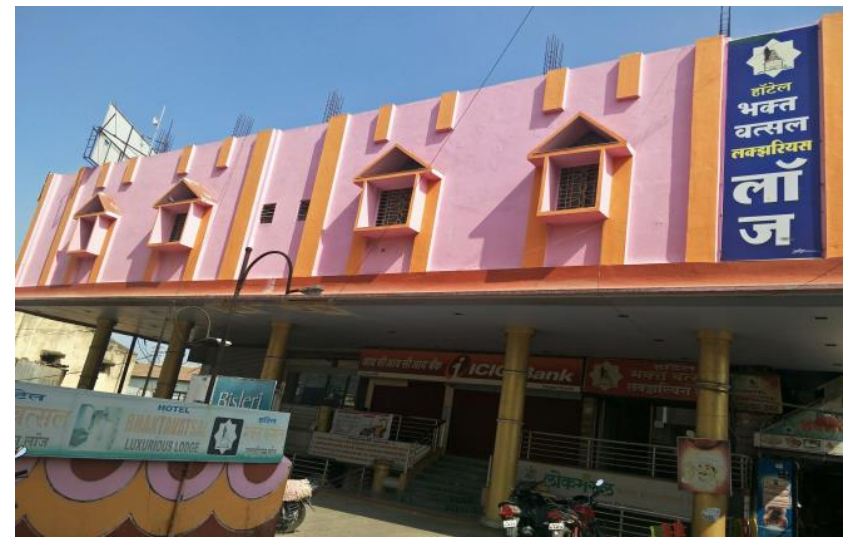

Fig.1 Front view windows with chajja and vertical fins (Site photograph)

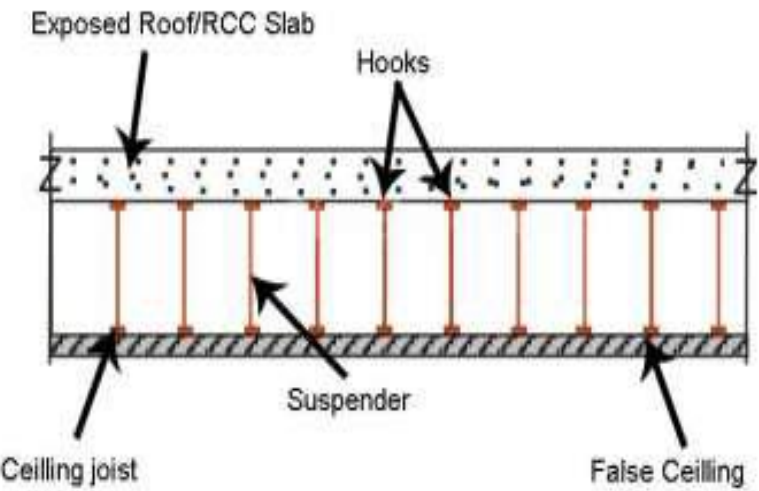

Fig. 2 Source www.google.com
The exterior walls on the first floor four sides had been constructed in garden trap bond masonry $230 \mathrm{~mm}$ wide, an air gap of $100 \mathrm{~mm}$ is kept between inside and outside the skin of brickwork. (Fig.3 and 4)The thermal conductivity of air is $0.026 \mathrm{w} / \mathrm{m}^{2} / \mathrm{k}$ at $25{ }^{\circ} \mathrm{C}$ this air gap reduces heat transfer from outside to inside air and increases soundproof ness inside the rooms.[6] This air inside the cavity of rat trap bond becomes hot by conduction of heat due to solar radiation outside. It may create the thermal stresses and development of cracks on the wall surface externally.

This hot air is to be released to the outdoor atmosphere by PVC pipe $11.5 \mathrm{~mm}$ diameter fitted at various places in an exterior wall.

The long passages provided in between rooms are 1.2 meters wide with one side opening for doors of rooms and an opening door for two suit rooms at the ends. This passage is served with windows on both sides and the used air from passages and rooms has been taken upside by providing 1.2-m x $1.2 \mathrm{~m}$ air duct.This is connected to passge through louvered windows. This air duct is provided at the center of passage covered at the top side with a transparent plastic sheet. The steel mesh on four sides was provided as an exit for stale air from passages to the surrounding ambient air.

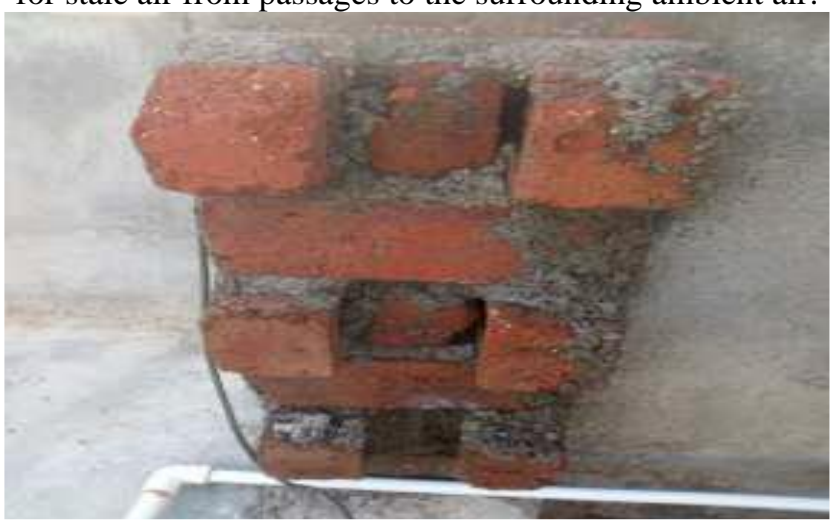

Fig.3 Rat trap bond (Site photograph)

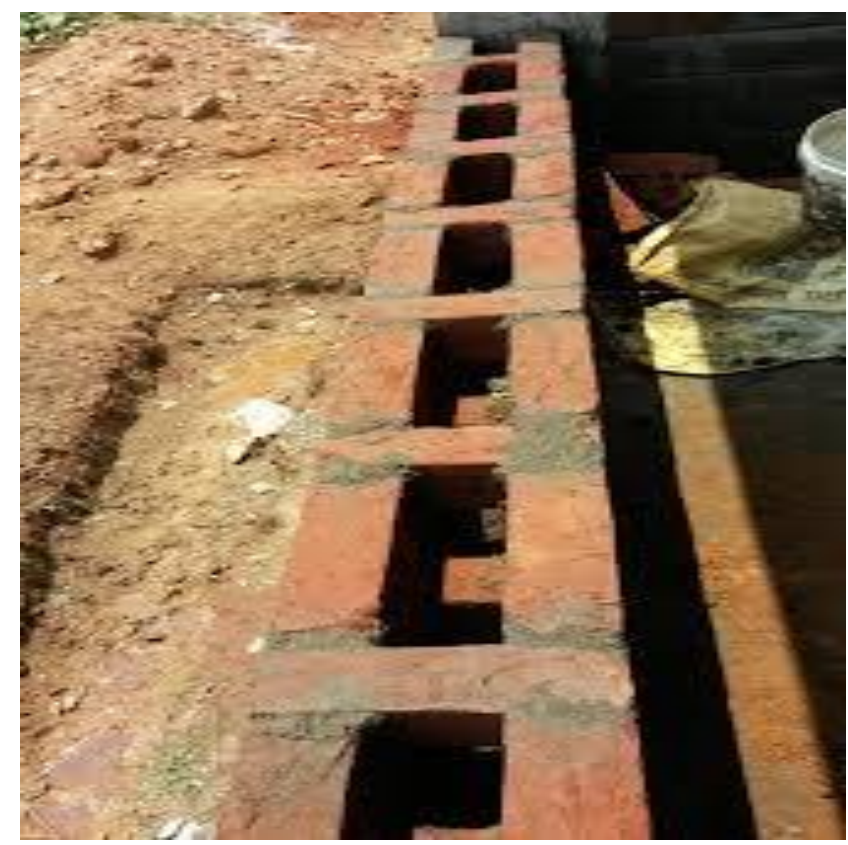

Fig.4 Source www.facebook.com 
This hot air in the air gap released to the outdoor atmosphere PVC pipe $11.5 \mathrm{~mm}$ diameter fitted at various places in an exterior wall. Fig.6

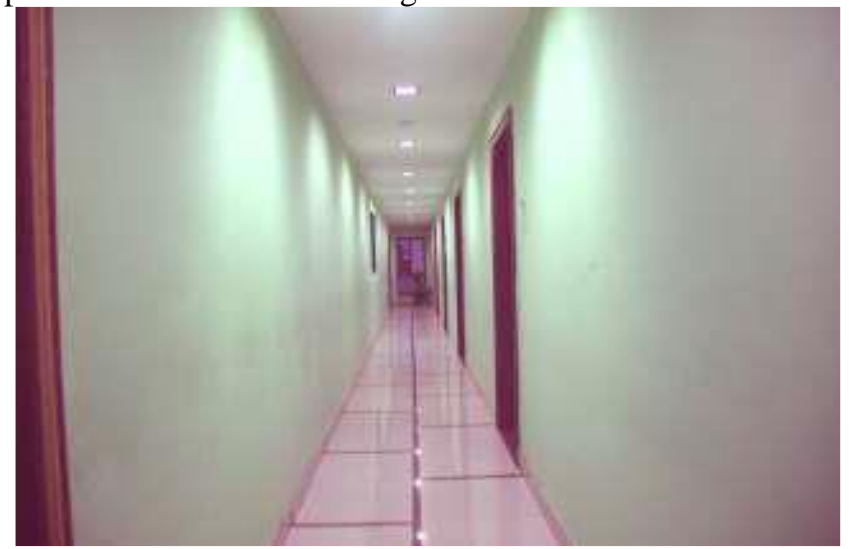

Fig.5 Passages connecting windows and air ducts. (Site photograph)

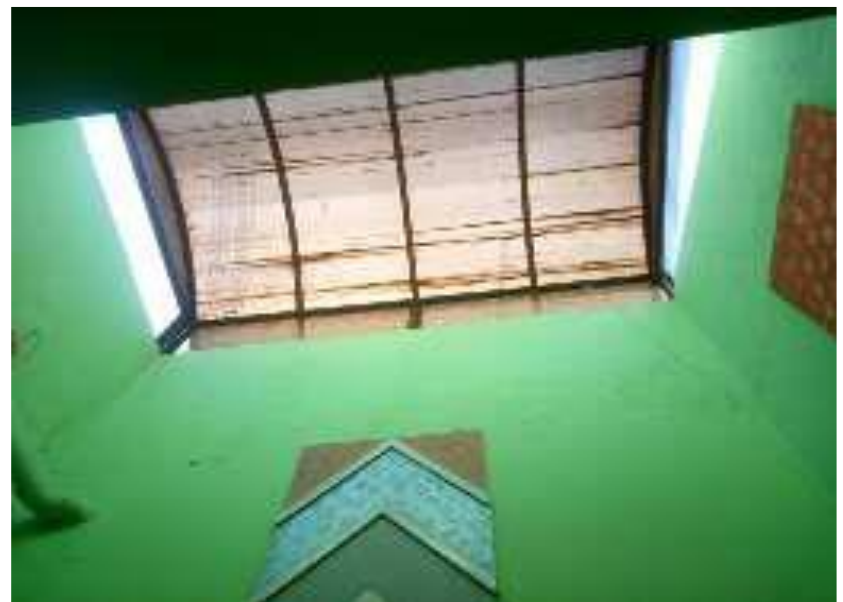

Fig.6 Air ducts view from inside (Site photograph)

The windows provided in common passages on the north and south side provide cross ventilation for air circulation and to remove stale air from these sides. These windows opening area were provided with $20 \%$ of the floor area offering indoor wind velocity $25 \%$ of outdoor wind velocity. (Fig.5,Fig. 6) The exterior part of the building is plastered smooth whereas on the inside part of a wall plaster of Paris had been applied with light colors. The plaster of Paris coating material has a property of lower down thermal conductivity by absorbing air moisture. It maintains indoor air temperature at a lower level. A transom window is provided for allowing only longwave diffused sun rays inside the room at deeper lengths. (Fig.7)

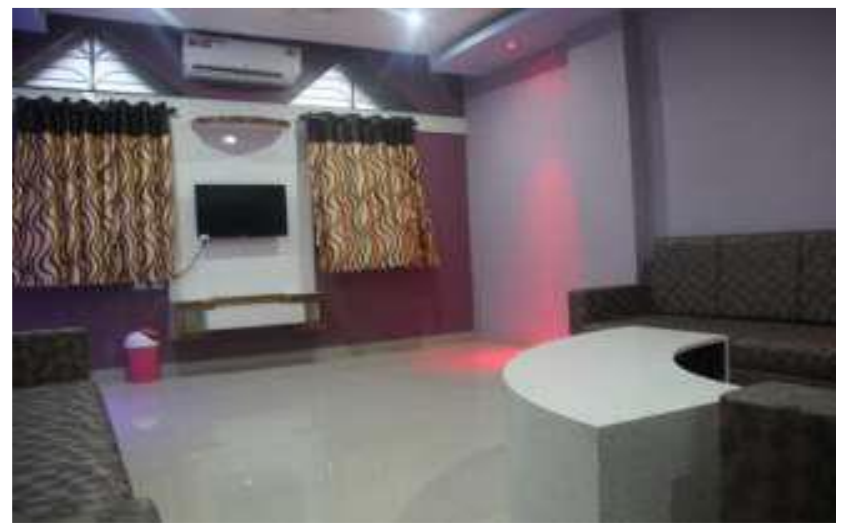

Fig.7 A transom window (Site photograph)

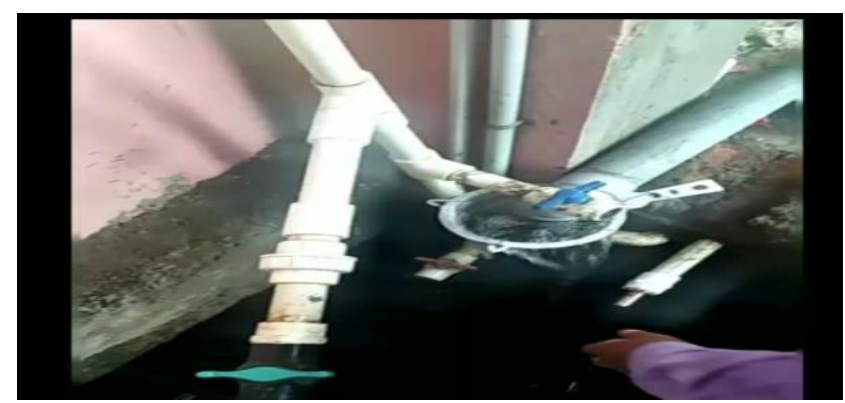

Fig.8 Rain water harvesting works (Site photograph)

A semi underground floor consisting of commercial halls is provided with a height of 2.5 meters deep below the ground and 1.2 meters above the ground. The earth berm is constructed by filling murum, soil on for sides of semi underground floor.[4] This acts as heat sink in summer and winter keeping comfortable indoor conditions in both seasons. Water conservation for the building was done by collecting rainwater from the front entrance and the slab terrace with a pipe system was approximately 3.25 lakh liters per year. The rainwater collected is stored in an underground water tank and for tube well recharge after filtering through devas type water filter media. (Fig. 8).

\section{OBSERVATIONS}

Temperature measurements were carried with scientific thermometers at outdoor and indoor locations of the basement of the building, passages on the first floor, room no. 106 and suite rooms to check the effectiveness of air cooling with respect to the above passive cooling technologies. The reading of temperature was taken on 23/05/2016 with 15 minutes interval basis, the graph shows variations in temperatures.

Fig.7.1 Chart showing the reduction in indoor temperature in basement floor.

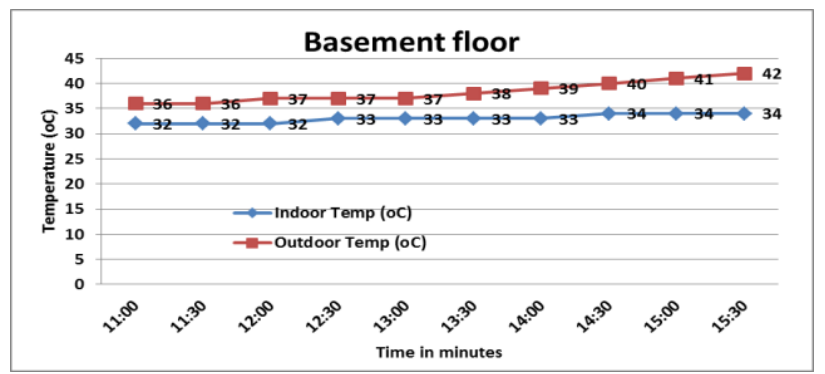

Fig. 7.2 Chart showing the reduction in indoor temperature in first floor passage

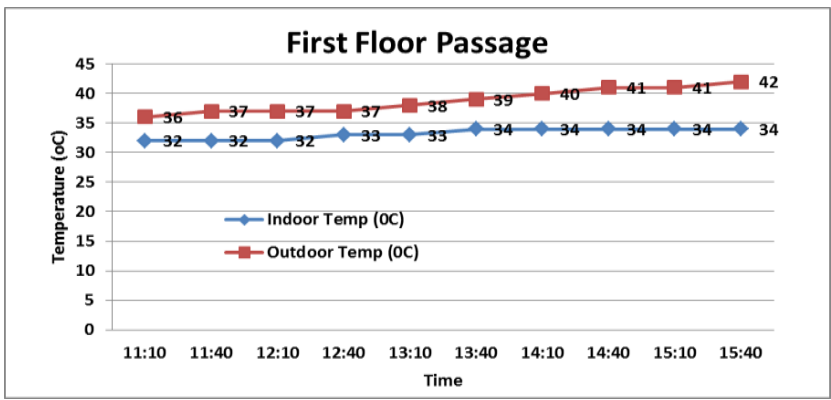

Fig. 7.3 Chart showing the reduction in indoor temperature in room no. 106

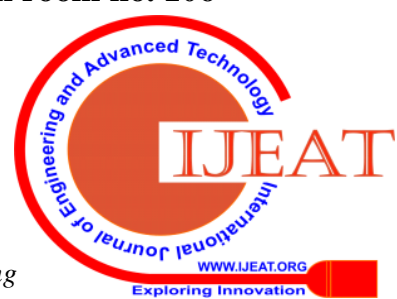




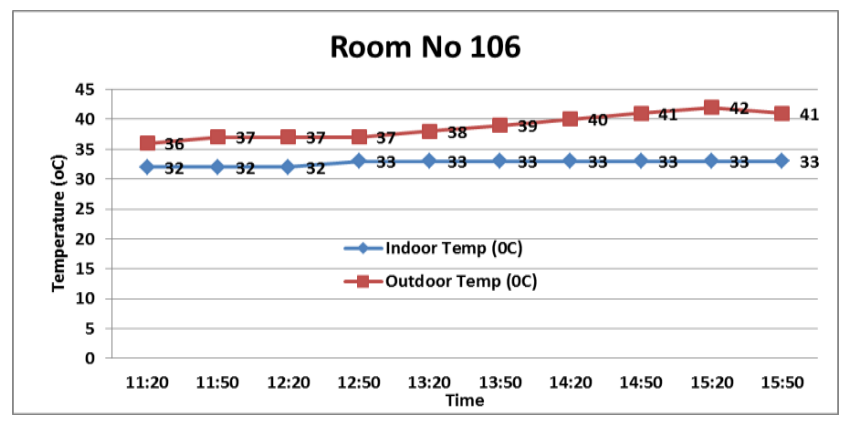

Fig.7.4 Chart showing the reduction in indoor temperature in Suite no. 3

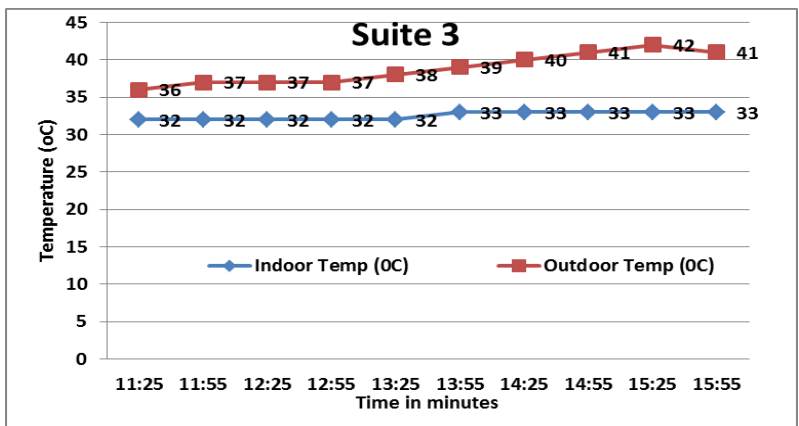

\section{RESULT AND DISCUSSIONS}

It was observed from above graphical analysis that, the temperature of the ambient atmosphere varies from $36{ }^{\circ} \mathrm{C}$ to $34^{\circ} \mathrm{C}$, in a day whereas the indoor temperature in basement and passages in the first floor varies from $32{ }^{\circ} \mathrm{C}$ to $34^{\circ} \mathrm{C}$. The indoor temperature in room no. 106 and suite are from $32^{\circ} \mathrm{C}$ to $33^{\circ} \mathrm{C}$ the graph shows that present passive cooling technologies had a cumulative effect on reduction in indoor air temperatures.

\section{FUTUER SCOPE OF WORK}

Earth air tunnel (EAT) system had been installed with underground $1500 \mathrm{~mm}$ diameter PVC pipes buried at 3.65 meters deep with inlet and outlet arrangements. The open ducts has been provided for passive downdraft evaporative cooling (PDEC) system had been constructed in the building at first floor but it was not operational till today. The cooling performance of these systems couldn't be assessed at this stage of work it can be a part of the future scope of research work for cumulative effect of indoor air cooling.

\section{CONCLUSION}

Energy conservation in indoor air cooling of building with the use of various air cooling technologies had been described in this work. The field experimentation for temperature measurements had been conducted in a commercial building. The graphical analysis of this experimentation conducted at various locations in the building had been done with discussions. It was observed that average temperature reduction in the indoor atmosphere was found to be $3^{\circ} \mathrm{C}$. The energy cost required to reduce the indoor air temperature by $3^{\circ} \mathrm{C}$ is saved every year. This cost-saving in energy requirement is huge considering the total life span of the building (80 years life in case of R.C.C..building). It can conclude that for efficient indoor air cooling these technologies must be integrated into the design phase of building. These technologies used in a building can reduce electrical energy consumption and reduce the load on conventional refrigeration and air conditioning systems for ecological preservation on the planet.

\section{REFERENCES}

1. Agrawal, A., Jain, R. K., \& Ahuja, R. (2005). Shekhawati: Urbanism in the semi-desert of India - A climatic study. 22nd International Conference, PLEA 2005: Passive and Low Energy Architecture Environmental Sustainability: The Challenge of Awareness in Developing Societies, Proceedings, 1, 425-430.

2. Inanlou, H., \& Ataee, S. (2017). Application of Geographical Location Differences of the Sun-Path Diagram in Climatic Architecture. Space Ontology International Journal, 6(3).

3. F., Nejat, P., Calautit, J. K., Yusof, M. B. M., Zaki, S. A., Hughes, B. R., \& Yazid, M. N. A. W. M. (2017). A review on windcatcher for passive cooling and natural ventilation in buildings, Part 1: Indoor air quality and thermal comfort assessment. Renewable and Sustainable Energy Reviews, Vol. 70, pp. 736-756. https://doi.org/10.1016/j.rser.2016.11.254An.

4. Kamal, M. A. (2012). An Overview of Passive Cooling Techniques in Buildings: Design Concepts and Architectural Interventions. Civil Engineering \& Architecture, 55(1), 84-97.

5. Macias, M., Gaona, J. A., Luxan, J. M., \& Gomez, G. (2009). Low cost passive cooling system for social housing in dry hot climate. Energy and Buildings, 41(9), 915-921.

https://doi.org/10.1016/j.enbuild.2009.03.013A

6. Nayak, J. K., \& Prajapati, J. A. (2006). Handbook on Energy Conscious Buildings. $R$ \& D Project No. 3/4(03)/99-SEC between Indian Institute of Technology, Bombay and Solar Energy Centre, Ministry of Non-Conventional Energy Sources, 4(3), 2093-2117.

7. NITI Aayog and IEEJ. (2017). Energizing India, A Joint Project Report of NITI Aayog and IEEJ, Details available on http://niti.gov.in/writereaddata/files/document_publication/Energy\%20 Booklet.pdf, Accessed on 31st March, 2018. https://doi.org/10.1016/j.ijcard.2017.07.068

8. Pablo La Roche. (2005). Smart Passive Cooling Systems for Sustainable Architecture in Developing Countries: Using the Gap To Bridge the Gap. World Sustainable Building Conference, 2005(September), 27-29.

9. Thomas, L., \& Baird, G. (n.d.). Post-occupancy evaluation of passive downdraft evaporative cooling and air-conditioned buildings at Torrent Research Centre, Ahmedabad, India

\section{AUTHORS PROFILE}

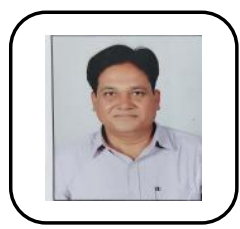

P. A. Hangargekar, Research scholar, MGM'S JNEC, Aurangabad, India. pradeeppah@gmail.com Author is $\mathrm{PhD}$ research fellow JNEC Aurangabad and assistant professor in STB College of engineering Tuljapur. He has completed his master's degree in environmental engineering

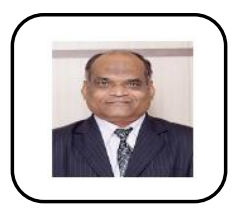

Dr. K. R. Harne, Professor, Department of CE,CBP Government engineering college New Delhi, India. Author is research dean in CBP Government engineering college New Delhi. He was past Principal of various engineering college in Maharashtra. 